\title{
Storytelling as a Tool of Authentication in Jazz Discourse
}

\section{Sven Bjerstedt}

The term "storytelling" is very often used as a prestige word in discourse on jazz improvisation. This usage is exemplified and discussed in this article through quotations from my recent dissertation, which includes extensive qualitative interviews with fifteen Swedish jazz musicians of national and international renown. In this article, I will present a number of quotes from these interviews, focusing on the musicians' comments on how they perceive the term storytelling as a picture or description of what jazz improvisation is about.

Pianist Lars Jansson contends that a jazz solo must have "soul" or "content." It ought to mirror the musician's own life:

\begin{abstract}
You have to tell a story when you play a solo. It's an abstract thing. You don't tell it in words, you tell it in notes when you tell it in a solo, an improvisation. But clearly, if a musician only plays with masterly skill but with no soul or content, the listener will often get tired. You want to be touched by the one you hear playing. And that goes for all great musicians such as Billie Holiday and Coltrane and Miles and Bill Evans, that is, they mirror their own life in their playing, their music. And that is what touches us. So content is extremely important. (Bjerstedt 233)
\end{abstract}

It is clear from the interviews I conducted with Swedish jazz musicians that the storytelling in jazz solos is something that musicians actually talk about and relate to. Comparing a number of great saxophonists through jazz history, saxophonist Roland Keijser remarks that they tell "very different kinds of stories" (qtd. in Bjerstedt 215).

I suggest that the concept of storytelling has too often been taken for granted in jazz discourse, even in academic discussions of jazz music, and that critical assessment of this metaphor is long overdue. The usage and its implications are the object of study in my doctoral dissertation, which includes an empirical investigation based on extensive qualitative interviews with Swedish jazz improvisers. Their descriptive and prescriptive usage of the term "storytelling" in discussions on jazz exemplifies how metaphor may function in this context when a term (storytelling) is borrowed from one mode of artistic expression (oral narrative) and applied to another one (jazz music). Arguably, this is but one example out of several instances where art forms, or artists, tend to mirror themselves in each other in order to understand themselves better.

This phenomenon could be studied and discussed from several perspectives: for instance, artistic, educational, and sociological. To begin with, theoretical perspectives on metaphor are relevant to our understanding of storytelling with regard to jazz improvisation. In the words of Michael Parsons, "[t]he arts don't just use metaphors, they invent them" (539). The "interactive level of metaphor" has been the topic of much debate in later years, in part incited by Max Black's view of metaphors, especially his statement that "metaphor creates the similarity" (37). The meaning(s) of the storytelling metaphor in the jazz context-as I. A. Richards and Paul Ricoeur would likely contend-cannot reasonably be expected to be found in a dictionary, for the meaning of the storytelling metaphor is carried by discourse.

Furthermore, Keith Swanwick makes a crucial point regarding the "bi-directionality" of musical metaphor. On one hand, the term "storytelling" may function as a metaphor for a specific kind of music, namely, jazz improvisation. On the other hand, as Swanwick points out, music consists of musical tones that are also metaphors in that they are perceived as expressive shapes: in Swanwick's words, “tones' are heard as 'tunes'" (499). Theoretical perspectives on metaphor are further pursued in my dissertation, but will not be my main focus in this article.

The focus here, rather, is to discuss a few aspects out of the multitude of perspectives on the sociology of jazz and jazz education that may prove relevant to issues of metaphorical usage in the context of jazz improvisation. Of course, no storytelling in a literal sense is going on in instrumental jazz music. I argue that the use of this term in jazz discourse is an instance of a "rich intermedial metaphor." The meanings of words may-and will—transform along the way. Words are characterized by much fickleness and little solidity. Ever rambling, words get the meanings we decide for them and are used the ways we decide to use them.

I suggest that it may be especially useful, following Potter's view on "talk and texts as social practices" (105), to take a closer look at the discursive construction of one concept that is at the heart of discourse on improvisation: authenticity. Issues of musical authenticity have been the subject of much debate with regard to several musical genres, especially, perhaps, genres emanating from folk music (Hamm 12-16). I will argue that the concept of authenticity is closely related to the notion of jazz as storytelling. Issues of authenticity and authentication in Swedish 
jazz emerge as one important focus in my recent interview investigation, in which I asked Swedish jazz musicians to comment on how they perceive the term storytelling as a picture or description of what jazz improvisation is about.

\section{Voice, Sound, Tone}

Several of my interlocutors concur with the importance of the instrumental sound that is sometimes referred to as the musician's "voice." To them, the sound is essential to successful jazz improvisation. I suggest that this view on voice and sound could be interpreted as the musicians' own perspective on music as metaphor in Swanwick's aforementioned sense: musical tones as expressive shapes. Saxophonist Roland Keijser points out that the sound that will make the most credible story in jazz improvisation is probably not the neutral sound of a classically trained musician's approach (Bjerstedt 260). Saxophonist Joakim Milder sums up what matters to him when listening to jazz improvisation: "I look for voices, really, to a great extent." He thinks of judging a soloist's sound as a matter of "physical attraction" (qtd. in Bjerstedt 257). The impression of the voice may, in a way, be stronger than the impression of the story, according to saxophonist Lennart Åberg; he may not experience so much when Miles Davis "tells any story, but he creates moods and expressions that are general in a way. A feeling of life or something like that" (qtd. in Bjerstedt 231).

Pianist Elise Einarsdotter attempts to explain why some musicians convey so much more than others: "It has a lot to do with the tone, I think. The intention and the tone" (qtd. in Bjerstedt 210). Bassist Anders Jormin speculates that "in the storytelling phenomenon there may be this connection between expression and voice." For instance, he describes the saxophonist Wayne Shorter's voice as "the most storytelling one," "thunderous," "extremely firm and apparently convinced" (qtd. in Bjerstedt 211).

Åberg recalls how Clark Terry employed differences in sounds-notably referring to instrumental sounds, not to Terry's well known vocal "mumbles"-for storytelling purposes: "that gimmick, switching with fluegelhorn, so that he played a duet with himself, kind of. And he produces phrases just like talking, in a way, instrumental. With his sound and all. You know, he has a very special sound. You could speak of storytelling there. Even dialogue" (qtd. in Bjerstedt 216). As I interpret these remarks, one crucial perspective in my interlocutors' views is that the "story" included in a jazz improvisation resides, to an important extent, in the instrumental "voice" of the improviser.

\section{Openness}

In the interviews, different qualities are put forward as prerequisites for successful storytelling in jazz improvisation: for instance, being open, being present in the moment, being able to listen both to others and to one's inner voice. The mental state of "openness" emerges as an important requirement. Trumpeter Ann-Sofi Söderqvist finds it best to be "open to the fact that things can go in different directions in a way, and not try to govern it too much." In her opinion, improvisations come out best "when you don't know what you're doing, when you forget yourself, [. . .] when you feel that you are one with [. . . ] this canal, [this] higher spirit that you're connecting to" (qtd. in Bjerstedt 253). In a similar vein, saxophonist Jonas Kullhammar describes the ideal, trance-like state in the improviser: "The brain isn't there" (qtd. in Bjerstedt 253).

Discourse on improvisation has often tended to focus on the thoughts of the improviser, manifested in the title of Paul F. Berliner's unsurpassed ethnographic study: Thinking in Jazz. There may also be reason to approach jazz improvisation with a broader or alternative outlook. Some theorists point to the importance of "not thinking" when you improvise. Sawyer, summing up results of his interviews with jazz musicians, finds that they "believe that their solos are better when they are minimally conscious" (257). Based on the results of my recent ethnographic study, I suggest that such a perspective ought to be regarded not as some sort of primitivist argument but as an interesting and important complement to the focus on the improviser's thoughts.

Several of my interlocutors agree on the importance of being there in the moment. Saxophonist Joakim Milder says, "We get charged by the moment." He also offers a few prescriptions in order to attain this state: "Not to stand in your own way. Not to think. Not to fulfil expectations. Not to try to express something specific" (qtd. in Bjerstedt 254-255). Pianist Lars Jansson speaks of going into the present as a "mystic quality," "very simple and basic," "a deeper happiness" (qtd. in Bjerstedt 254). To singer Lena Willemark, being present is the essence of storytelling in improvisation: "The great discovery of being present. [. . . ] That may be what it is to tell a story." In her view, to be present requires a mental state of openness: "When I'm in openness I can feel being a part of the great [. . .] that can happen like a flash [. . . I I become whole" (qtd. in Bjerstedt 255) Several of my interlocutors emphasize that thinking and planning will only be a hindrance to playing; in comparison, thinking is too slow. 
The ability to listen is one important aspect of being open in the present moment. Bassist Anders Jormin hypothesizes on an historical background to the Nordic jazz approach sometimes referred to as "fjälljazz" [fjeld jazz]: maybe, he says, its ingredients of breathing and listening-which may perhaps by some be perceived as more predominant here than in most American jazz-could be culturally conditioned, building on "a comparatively long tradition of no wars, [ . . ] of democracy, [ . . .] of counsel, discussing and listening to others before you make a decision [. . . ] a tradition of listening as much as talking" (Bjerstedt 270). While Jormin refers to an old Scandinavian democratic tradition, his statement also evokes interesting questions about the relation in general between jazz and democracy, which of course is also at the core of a central and pervasive American jazz metaphor.

Listening to others is important, but listening to oneself is crucial, too. The jazz improviser's "inner voice" is often mentioned by my interlocutors. Furthermore, several of them emphasize the importance of balance in the improviser's musical craftsmanship: balance between knowledge and expression, between sense and sensibility, between being serious and easy-going, and between polarities in life such as humour and melancholy, or joy and pain. All of these aspects are put forward as important with regard to the credibility of the "story" that is told by the improviser.

\section{The "How" of Playing}

Narrativization of music may be dependent on cultural competence (Wittgenstein 29e). In the African American jazz tradition, certain cultural practices_often termed "Signifyin(g)"-permeate both performing and listening activities regarding jazz improvisation (Gates; Floyd, Power). These practices are characterized by double meaning, double consciousness, and double-voiced discourse. They include a large number of aspects of jazz improvisation, such as the importance of transformation of preexisting musical material, playing on cultural memory while playing with musical ideas; the relation between the music and the life of the performers and the audience; the importance of embodiment or the performers' physical play.

The views of my Swedish interlocutors on jazz improvisation seem to adhere in several respects to qualities that are prominent in African American traditions. Several sources agree that in African American music, the "how" of a performance, meaning the physical movements, the "material manifestations of Signifyin $(\mathrm{g})$," is more important than the "what," or the sonic gestures (Gates 70; Floyd, Power 97). Notably, while Signifyin(g) is grounded in African American culture and perhaps linked to African cultural memory, several of my Swedish interlocutors chime in with this perspective. Saxophonist Joakim Milder speaks of Wayne Shorter's shifting between high and low soloistic activity: "Everything is governed by and depends on what needs to be expressed. So it isn't centred on his achievement. At all, really" (qtd. in Bjerstedt 211). I interpret Milder's term "achievement" to refer to the mechanics and technique of Shorter's playing. Speaking to the how of playing, saxophonist Gunnar Lindgren especially emphasizes the importance of having "life in the ornaments" in jazz improvisations (qtd. in Bjerstedt 235). In the same vein, trumpeter Peter Asplund describes the jam sessions and cutting contests of the Swing Era not as a matter of playing loud and strong, but of reaching the audience emotionally: this he terms "storytelling on a high level" (qtd. in Bjerstedt 234). Saxophonist Nisse Sandström, speaking of how the "rhythmic message" of Stanley Turrentine makes him hear "a black priest," states that "It is about how you convey this" (qtd. in Bjerstedt 212). Sandström's statement seems to be based on implicit assumptions about aesthetics and race, and though it may be difficult to fully explore its meaning, I find it interesting to note how his view seems to corroborate the ones cited above on the material manifestations of Signifyin $(\mathrm{g})$.

\section{Discursive Construction of Musical Authenticity}

George E. Lewis proposes a distinction between Afrological and Eurological modes of improvisation: the latter is exemplified by the music of John Cage. Such improvisation, Lewis suggests, is (ideally) unaffected by the improviser's sociocultural context. Needless to say, this construct is hardly unproblematic; it could be questioned whether such an ideal is ever really possible. There is nothing in the results of my study to suggest that Swedish jazz musicians aim at that kind of mode in their improvisations. On the contrary, sociocultural aspects-though seemingly not the primary focus-are present in the interlocutors' perspectives. This result is in tune with the contention of Stuart Nicholson that Signifyin(g) may well be relevant to European jazz, but because its cultural and historical background differs from that of (African) American jazz, it draws on "a different cultural heritage" (177). The "cultural memory" (Floyd, Power 233), though different in content, is relevant. Obviously, cultural memory is not monolithic. It is noteworthy that many Swedish musicians, when reflecting on their craft, turn to American terminology and musical exemplars. Following Ingrid Monson, it might be argued that even though Swedish musicians may "reach beyond their sociologically defined categories" and master many parameters of African American musical styles, their social relationship to the music will still be a different one (34). 
According to the interview statements, as a jazz improviser one needs to relate to one's cultural memory while also being true to oneself. In this regard, authenticity emerges as a key concept. Notably, an artist could be said to be authentic to at least two different things: to the tradition in which s/he is working, or to her/his self. Arguably there are differences in the dynamics of authenticity regarding on the one hand the tradition in which the improviser is situated, and on the other the improviser's individuality. I propose that, although the concepts are by no means mutually exclusive, the notions of "tradition-authenticity" versus "self-authenticity" may be useful when we try to understand discourses of jazz music as storytelling.

In an influential article on authenticity in music, Alan Moore advocates a shift of focus from performer to listener. He points out that in order to understand better what "authenticity" in musical performance may refer to, we ought to focus not so much on the originators' intentions, but rather on the reasons that various perceivers may have to find a performance authentic. Authenticity, Moore holds, is not inherent in musical sound; rather, it is a matter of interpretation: "It is ascribed, not inscribed" (210).

In accordance with the argument put forward by Moore, musical authenticity ought to be viewed as a matter of interpretation: authenticity is not inherent in the musical sound. The notions of self-authenticity and traditionauthenticity relate closely to Moore's concepts of "authenticity of expression" (first-person authenticity) and "authenticity of execution" (third-person authenticity) respectively (214-220). There is, of course, a significant cultural and geographical distance between Swedish improvisers and the African American jazz tradition. While my Swedish interlocutors clearly find tradition-authenticity (or, third-person authenticity) important, one major finding in my interview study is that they, on the whole, seem to attach much greater significance to self-authenticity (first-person).

Obviously, these perspectives are not mutually exclusive. Rather, the views on jazz improvisation as cultural memory and as personal narrative complement each other. In line with Charlie Parker's words, "If you don't live it, it won't come out of your horn," several writers mention the inclusion of personal narrative in solos as an important quality in jazz improvisation (Floyd, "Ring Shout!"; Berliner; Lewis; Marsalis and Hinds; Berendt and Huesmann). Granted, these sources may be viewed as providing rather vague ways of formulating the general notion that art will often reflect the artist's life. I still find it interesting that so many of my interlocutors in the present investigation attach much more significance to jazz improvisation as expression of personal experience than to jazz as playing on cultural memory.

Bassist Anders Jormin regards improvisation as "the form of music where you have the possibility to play yourself [. . .] a form of music which demands you and me [. . .] improvisation to me isn't a style; it's personal expression" (qtd. in Bjerstedt 210). Pianist Elise Einarsdotter finds that "[s]ometimes a note can actually tell of a whole life. [. . . It's about life energy. And that energy is communicated" (qtd. in Bjerstedt 267). Saxophonist Roland Keijser holds that when improvising in jazz, "you always tell about yourself" (qtd. in Bjerstedt 267).

Saxophonist Gunnar Lindgren says, "Storytelling, that's exactly what it begins and ends with. [. . .] It really is the story of the heart, and it doesn't matter whether it's told through a saxophone or through a line and a gesture in a theatre. It's really the same thing. [. . .] an expression which is just his own [. . .] a kind of sincerity and naturalness [. . .] authentic and credible" (qtd. in Bjerstedt 208). Remarking on the importance of authenticity, Lindgren reacts negatively to the ambitions of a fellow saxophonist to be like "an excellent actor," to "go into any part whatsoever [. . .] I find it difficult to accept his view" (qtd. in Bjerstedt 217).

Pianist Lars Jansson says, "If you think about storytelling and you identify it as [. . .] content in music, then maybe you have to be a little older, too. [. . . ] Experienced more things. [. . .] if you tell stories from your heart, then you carry your own luggage" (qtd. in Bjerstedt 207). Saxophonist Lennart Åberg perceives lack of self-authenticity in an improviser to be the result of attempts to illustrate or imitate a true expression of something, rather than really expressing it (Bjerstedt 225). Speaking of contemporary Swedish musicians, saxophonist Nisse Sandström expresses his wish to hear "pain" and "joy" in their playing: it should "go straight to my heart" (qtd. in Bjerstedt 239).

In sum, my interlocutors do not necessarily interpret "storytelling" in jazz improvisation as a narrative structure. Rather, it is interpreted in a non-literal, non-narrative manner as a statement, as an expression of the player's own emotional experience. In the opinion of several of the musicians I interviewed, such an expression ought to be put forward in a direct and truthful way.

\section{Tradition-Authenticity Versus Self-Authenticity}

A large number of statements such as these point to the importance of personal narrative in Swedish jazz musicians' outlook on their craft. However, comparatively few statements from my Swedish interlocutors point to an interest in perspectives of cultural heritage, let alone to an interest in perspectives of double meaning, indirection, or allusion. 
Based on these results, it might make sense to speak of a difference between "American" and "Swedish" (or "Scandinavian") storytelling in jazz. Such a distinction may relate in interesting ways to a difference between two kinds of authenticity - I suggest the terms "tradition-authenticity" and "self-authenticity." These perspectives might be viewed in terms of differences in master narrative. Individual stories that are "told" in individual jazz improvisations may relate to larger narrative patterns. Sidney Bechet viewed African American music as expressive of cultural memory: "There had to be a memory of it behind the music" (qtd. in Floyd, Power of Black Music 8). Needless to say, oversimplification must be avoided. However, even a decidedly anti-essentialist scholar such as Ronald Radano, who cautions against the temptation to deny the "multiple and complex levels of meaning" (37) in musical experience or to view all jazz practices as instances of "indirection" (303), adheres to the view that a distinctive feature of black music is "the musically articulated resistances to an overarching white racial supremacy" (39). If Signifyin(g) on conditions of poverty, injustice, and oppression may have been ingredients in one master narrative of some African American jazz improvisers, then it is reasonable that some Scandinavian jazz improvisers, given their differences regarding social conditions, should relate mainly to alternative master narratives. In a sense, this perspective may be seen as another way of formulating the importance of sociocultural context to the improvisational outcome of individual artists. Different cultural and historical frameworks will prompt different master narratives, different individual jazz improvisational "stories"—different music.

This outlook arguably includes the perspectives of audiences as well as performers. A story is intended; a story is told; a story is understood. Regarding the latter perspective, one interesting and relevant aspect is put forward in John Neubauer's claim that listeners' re-employment of music varies depending on different cultural conditions (123). In brief, the story, as understood by the listener, is not necessarily the story intended by the performer. Generally speaking, senders' intentions and recipients' interpretations do not necessarily coincide. While beyond the scope of the present article, a future interview study focusing on listeners' experiences emerges as a logical and very tempting follow-up investigation.

Modes of communication come about in response to human needs. Ambiguity may, of course, be called for when the possibilities to express oneself unambiguously are restrained. It might be argued that a language of implication, of double meaning, may not have developed in the same way in Scandinavian jazz improvisation because freedom of speech has been comparatively unrestricted in this part of the world: consequently, indirection as a mode of musical expression may not have been needed in the same way as in African American culture. Similarly, in Swedish comedy, the concept of satire has arguably not developed, for instance, in the same way as in non-democratic Eastern European countries during the Cold War. Hence, Mikhail Bakhtin's concepts of dialogism and double-voiced discourse (Dialogic 324), though eminently adequate to the analysis of African American jazz, may arguably be somewhat less relevant in some European contexts.

\section{Problematizing the Dichotomy}

The dichotomy of the two authenticities of tradition and self could arguably be resolved: it is merely a superficial tradition-authenticity that would employ only idioms, gestures, and phraseologies out of the tradition, but would not include the requirement of self-authenticity, arguably also a part of that same tradition. For practices of contemporary jazz improvisers to be fully and wholly in line with the ways in which jazz improvisation has traditionally been perceived, self-authenticity is arguably a relevant ingredient.

In his discussion of musical authenticity, Charles Hamm distinguishes between historical, stylistic, and social authenticity (12). These notions are doubtless of great value, especially in a historical or social study of the music. However, the distinction suggested here between tradition-authenticity and self-authenticity is arguably of some importance in order to clarify what is actually said in jazz authenticity discourses. Importantly, yet paradoxically, any call for authenticity may be a symptom of a lack of authenticity. That is what nostalgia is about: a lack of that which it purportedly represents.

Lack of tradition-authenticity in a more rigid sense of the term-meaning lack of such things as relevant ethnic, cultural, and socio-historical background, including traditions of Signifyin(g) practices and perhaps even lack of relevant economic background-may be perceived by some as highly relevant to jazz performance, and by others as not at all relevant. Such questions of relevance depend on one's stance regarding issues such as traditionalism versus individualism, orthodoxy versus heterodoxy, etc.

Lack of self-authenticity, however, as indicated by the views of my interlocutors, can only be disastrous to jazz improvisational practice. While listeners may differ greatly in their evaluations of jazz that they regard as lacking in tradition-authenticity, there is probably significant agreement in their evaluation of jazz that lacks (in their opinion) self-authenticity. The jazz tradition, generally speaking, requires that the improviser be self-authentic in her playing: 
hence, as indicated above, the musician could perhaps not attain tradition-authenticity in a full sense without some sort of self-authenticity.

It is my impression that while storytelling may have been less prominent in discourse on Swedish twentieth-century jazz greats such as Lars Gullin and Jan Johansson, the concept of "voice" has figured as a rather important ingredient. In interpreting the tendency of the investigation, I suggest that Swedish jazz improvisers' emphasis on self-authenticity-or, in the words of Moore, first-person authenticity of expression-could arguably be understood in relation to the fact that the perceived distance to jazz improvisational role models may be larger than in the case of American jazz musicians. Obviously, one ought not to generalize regarding these issues. Still, I would suggest that the "third person" (in effect, the African American jazz tradition) may be perceived by some Swedish jazz improvisers as comparatively distant, perhaps unattainable even, to them. Consequently, the quest for first-person

(self-)authenticity may appear more relevant, realistic, and feasible to these musicians than an attempt to attain thirdperson (tradition-)authenticity.

The Italian musicologist Stefano Zenni points to the context of Signifyin(g) in European jazz: "When music is produced in Europe, it is logical that its signifyin' doesn't draw on blues or spirituals, of course, but on a different cultural heritage" (qtd. in Nicholson 177). It would seem, though, based on the results of the present interview study, that Swedish jazz improvisers do not conceive of indirection and allusions as especially important to their art, at least not to the extent suggested by Nicholson. Primarily, they value and aim at self-authenticity, seemingly finding that quality far more essential to their craft than playing on cultural memory in double-voiced discourse. I hold this to be a quite interesting result both from a general perspective, as an indication that musical improvisation is always situated in a socio-musical context, and in this particular context, as an indication of a distinctive character in Swedish or European jazz.

\section{Storytelling as Counter-Discourse}

There are several important cultural and educational sociological implications of the storytelling metaphor in the context of jazz improvisation. In line with the view that society, musical authenticity, and several other relevant concepts may be discursively constructed (Berger and Luckmann; Bourdieu; Hamm; Potter), the usage of the storytelling metaphor may arguably be interpreted as an inclusionist discourse and/or an exclusionist counterdiscourse.

As pointed out in Black's analysis, metaphors are interactive. To use metaphors is to re-describe reality. Thus metaphors do not only describe - they prescribe as well. The directive that every jazz soloist must tell a story was repeatedly and perhaps most famously put forward by Lester Young: "You're technically hip," he would tell fast young players, "But what is your story?" (qtd. in O'Meally 221). In the words of Radano, storytelling represents "one of the enduring rhetorical gestures among musicians, the principal trope conceptualizing the art of Lester Young, Charlie Parker, and so many others" (25). A term such as "storytelling" may be used in jazz improvisation contexts in order to prompt or accomplish actions in this field (to influence, teach, or evaluate practices of jazz improvisation, for instance). Jonathan Potter's notion of the offensive rhetoric of description emerges as a very apt perspective for how metaphorical descriptions may be used performatively, for how "the specific sense of something" may be constituted through categorization (177). Along these lines, musicians, teachers, or listeners may agree in an openly normative fashion that in order to function better, jazz improvisations ought to be (like) storytelling; however, the same term may also be used in the same contexts as an alleged factual description of reality—what Potter terms "reifying discourse"-that jazz improvisation is in fact storytelling, or else it is not jazz improvisation. For instance, in the very first sentence of his autobiography, very much in this vein, pianist and composer Randy Weston proclaims that "I come to be a storyteller; I'm not a jazz musician, I'm really a storyteller through music" (1).

There are different functions and effects of such discourses. Arguably, four kinds of groups may employ the storytelling metaphor as a kind of exclusionist counter-discourse:

(i) an older generation of musicians against a younger generation of musicians;

(ii) an (earlier) autodidactic, "uneducational" musical culture against a (later) educational culture;

(iii) a later, heterodox ("holistic" or "synthetic") educational culture against an earlier orthodox ("analytical") educational culture

(iv) a culture of genuine authenticity against a culture of technical proficiency. 
The latter category is arguably the oldest in jazz discourse, exemplified by Lester Young's utterance, "But what is your story?"

The dynamics of tradition and individuality stand out as central to these kinds of discourses. In the words of the philosopher Alasdair Maclntyre,

man is in his actions and practice, as well as in his fictions, essentially a story-telling animal. [. . .] But the key question for men is not about their own authorship; I can only answer the question "What am I to do?" if I can answer the prior question "Of what story or stories do I find myself a part?" (216)

Though Maclntyre's reflections on tradition may be cast in generic form, they seem equally relevant as a way of perceiving "prefiguration" in jazz improvisational storytelling and the tension between individual expression and frames of convention, between self-authenticity and tradition-authenticity, between freedom and mastery. When storytelling is viewed as a counter-discursive weapon employed by older, autodidactic, heterodox advocates of authenticity, philosophical perspectives on human existence in relation to human traditions are never far away.

\section{Works Cited}

Bakhtin, M. M. The Dialogic Imagination: Four essays. Ed. Michael Holquist. Trans. Caryl Emerson and Michael Holquist. Austin, TX: U of Texas P, 1981. Print.

---. Speech Genres and Other Late Essays. Trans. Vern W. McGee. Eds. Caryl Emerson and Michael Holquist. Austin, TX: U of Texas P Slavic, 1986. Print.

Berendt, Joachim, and Günther Huesmann. The Jazz Book: From Ragtime to the 21st Century. 7th ed. Chicago: Lawrence Hill, 2009. Print.

Berger, Peter L., and Thomas Luckmann. The Social Construction of Reality: A Treatise in the Sociology of Knowledge. 1966. London: Penguin, 1991. Print.

Berliner, Paul. Thinking in Jazz: The Infinite Art of Improvisation. Chicago: U of Chicago P, 1994. Print.

Bjerstedt, Sven. Storytelling in Jazz Improvisation: Implications of a Rich Intermedial Metaphor. Malmö, Sweden: Malmö Academy of Music, Lund University, 2014. Print

Black, Max. Models and Metaphors: Studies in Language and Philosophy. Ithaca: Cornell UP, 1962. Print.

Bourdieu, Pierre. "The Field of Cultural Production, or: The Economic World Reversed." The Field of Cultural Production: Essays on Art and Literature. Ed. Randal Johnson. London: Polity Press, 1993. 29-73. Print.

Floyd, Samuel A., Jr. "Ring Shout! Literary Studies, Historical Studies, and Black Music Inquiry." Black Music Research Journal 11.2 (1991): 265-87. Print.

---. The Power of Black Music: Interpreting its History from Africa to the United States. New York: Oxford UP, 1995. Print.

Gates, Henry Louis, Jr. The Signifying Monkey: A Theory of African-American Literary Criticism. New York: Oxford UP, 1988. Print.

Hamm, Charles. Putting Popular Music in its Place. Cambridge: Cambridge UP, 1995. Print.

Lewis, George. E. "Improvised Music after 1950: Afrological and Eurological Perspectives." Black Music Research Journal 16.1 (1996): 91-122. Print.

Maclntyre, Alasdair. After Virtue: A Study in Moral Theory. 3rd ed. Notre Dame, IN: U of Notre Dame P, 2007. Print.

Marsalis, Wynton, and Selwyn Seyfu Hinds. To a Young Jazz Musician: Letters from the Road. New York: Random House, 2004. Print. 
Monson, Ingrid. Saying Something: Jazz Improvisation and Interaction. Chicago: U of Chicago P, 1996. Print.

---. "Jazz as Political and Musical Practice." Musical Improvisation: Art, Education, and Society. Ed. Gabriel Solis and Bruno Nettl. Urbana: U of Illinois P, 2009. 21-37. Print.

Moore, Allan. "Authenticity as Authentication." Popular Music 21.2 (2002): 209-223. Print.

Neubauer, John. "Tales of Hoffmann and Others: On Narrativizations of Instrumental Music." Interart Poetics: Essays on the Interrelations of the Arts and Media. Ed. Ulla Britta Lagerroth, Hans Lund, and Erik Hedling. Amsterdam: Rodopi, 1997. 117-136. Print.

Nicholson, Stuart. Is Jazz Dead? (Or has it Moved to a New Address). New York: Routledge, 2005. Print.

O'Meally, Robert G. "Biography and Afro-American Culture: Response." Afro-American Literary Study in the 1990s. Ed. Houston A. Baker and Patricia Redmond. Chicago: U of Chicago P, 1989. 219-224. Print.

Parsons, Michael. "Art and Metaphor, Body and Mind." International Handbook of Research in Arts Education. Ed. Liora Bresler. Dordrecht, Netherlands: Springer, 2007. 533-542. Print.

Potter, Jonathan. Representing Reality: Discourse, Rhetoric and Social Construction. London: Sage, 1996. Print.

Radano, Ronald. Lying Up a Nation: Race and Black Music. Chicago: U of Chicago P, 2003. Print.

Richards, I. A. The Philosophy of Rhetoric. 1936. Oxford: Oxford UP, 1971. Print.

Ricoeur, Paul. The Rule of Metaphor: The Creation of Meaning in Language. Trans. Robert Czerny, Kathleen McLaughlin and John Costello. 1975. London: Routledge, 2003. Print.

Swanwick, Keith. "Metaphor and the Mission of the Arts." International Handbook of Research in Art Education. Ed. Liora Bresler. Dordrecht, Netherlands: Springer, 2007. 497-502. Print.

Weston, Randy, and Willard Jenkins. African Rhythms: The Autobiography of Randy Weston. Durham, NC: Duke UP, 2010. Print.

Wittgenstein, Ludwig. Zettel. Ed. G. E. M. Anscombe and G. H. von Wright. Trans. G. E. M. Anscombe. Berkeley: U of California P, 1967. Print. 